\title{
ABOUT THE PROBLEMS OF THE RESEARCH OF ORGANISMS INTERACTION WITH THE MICROWAVE RADIATION
}

\author{
S.N. Darovskih', darovskih.s@mail.ru, \\ Yu.S. Shishkova', shishkova_yulia@mail.ru, \\ N.V. Vdovina', nadzh@yandex.ru, \\ E.V. Vodyanitskiy', prorock_92@mail.ru \\ ${ }^{1}$ South Ural State University, Chelyabinsk, Russian Federation, \\ ${ }^{2}$ South Ural State Medical University, Chelyabinsk, Russian Federation
}

\begin{abstract}
The analysis of the main problems of studies of the organisms interaction with electromagnetic radiation in the microwave range is submitted. The controversial approach to assessing the role of microwave radiations of artificial origin for organisms is noted. One group of scientists considers these radiations as potentially dangerous to an organism, and the other group claims that under certain conditions they can be used in the medical purposes. The specified contradiction is eliminated by using exogenous approach to assessing the role of electromagnetic radiation in wildlife. In this regard in the article the operating role in the wildlife of the Sun microwave radiation reaching the surface of the Earth and the need for its simulation devices for reducing the negative impact on organisms of electromagnetic pollution is proved. The main results of microbiological studies using the developed hardware and software for simulation of the Sun microwave radiation in the superhigh-frequency range of wavelengths.

Keywords: heliobiology, homeostasis, microwave radiation, microorganisms.
\end{abstract}

\section{Introduction}

In the 30s last century the new scientific direction in biophysics arose by efforts of the Soviet scientist A.L. Chizhevskiy: "Geliobiology". For decades it caused interest in the scientific study of change patterns in solar activity on terrestrial organisms.

So far by the scientific school of A.L. Chizhevskiy it is authentically established [1] that in the periods of abrupt changes in solar activity there is deterioration in the condition of patients with hypertensive disease and atherosclerosis. In the same period of time violations of the functional state of the central nervous system take place, there is a spasm of the blood vessels, and a number of indicators of the curtailing and anti-curtailing system of blood changes, etc. Scientists collected statistical data on the repeatability of diseases among people and animals. The data confirmed the interrelation between epidemics and changes in solar activity. For example, influenza and other infectious diseases, "step" on people in days of the maximum solar activity. The mechanisms of the above changes in humans and animals and an aggravation of an epidemiological situation are not completely understood. However, most researchers are inclined to believe that the considerable part of the observed violations of homeostasis is directly connected with sharp perturbations of Earth magnetosphere, which arise under the influence of the corpuscular radiation of the Sun during substantial increases of its activity.

At the same time at the stationary course of physical processes on the Sun its favorable impact on organisms is noted. This point of view is proved by an outstanding Russian historian, a geographer and an ethnologist L.N. Gumilev [2]. His passionate theory of ethnogenesis is based on the periodic managing role of a space factor not of solar origin during the periods of activity decrease of the Sun.

All of the above indicates the complexity of the interaction of biological objects with physical processes taking place on the Sun.

The great contribution to the development of A.L. Chizhevskiy'sideas introduced a soviet scientist A.S. Pressman [3]. Without revealing the essence of the phenomena, he originated the idea of a special (information) interaction of organisms with electromagnetic radiation (EMR) and the fields of natural origin. The starting point of this assertion is the fact that the majority of the physical phenomena, in interaction with which the wildlife evolved, has an electromagnetic origin. For this reason it is possible to assume about the operating role in wildlife of this or that range site of electromagnetic radiation of 


\section{Инфокоммуникационные технологии и системы}

the natural origin which received as a result of development of organisms genetic fixing for ensuring their activity [4].

However, the paradoxical result of a large volume of studies on an assessment of the operating role in wildlife of electromagnetic radiations of the Sun consists that reliable information is got about negative effects of the radiation on organisms. This fact largely explains the reason of that over the last 10-15 years, the interest of scientists to actual heliobiology problems significantly weakened.

At the same time studies in the field of the assessment of the role of microwave radiations ${ }^{1}$ of artificial origin in wildlife didn't stop. Thus multidirectional nature of the received results indicates the existence of the conceptual problems underlying the understanding of the mechanisms of positive and negative effects on their objects of wildlife. It causes the relevance of carrying out the analysis of the main results of modern studies on the problem of assessing the organisms interaction with electromagnetic radiations of microwave range.

\section{Current approaches and challenges in assessing the role of microwave radiation in wildlife}

In recent decades in the field of studying the organisms interaction with electromagnetic radiation in the microwave range some scientific directions (research schools) with different, internally contradictory conceptual approaches to the assessment of operating role of EMR in wildlife were created. The first scientific direction (school of prof. Grigoriev Yu.G.) on the basis of numerous experimental studies proves the potential hazard to organisms of the electromagnetic environmental pollution [5]. An important result of the research is the assertion that sanitary standards and rules existing today which limit the levels of electromagnetic radiation, do not correspond to the knowledge of their danger which were obtained by scientists all over the world in recent years.

Other scientific direction dominating in biophysics is the school of acad. N. D. Devyatkov and his followers: prof. O.V. Betskij, prof. N.I. Sinitsyn, prof. V.F. Kirichuk and others. The scientists of this school claim that electromagnetic radiations of artificial origin (mainly millimetric range) can be used for therapeutic purposes. In the country and overseas hundreds of scientific articles were published to prove on the basis of the proposed research, such a possibility.

The idea of the possibility of a specific (resonant) effect of EMR of millimetric range of wavelengths on biological structures and organisms was proposed by Soviet scientists: acad. N.D. Devyatkova, prof. M.B. Golantand other in1964-1965. Its main content was as follows [6]. Millimeter radiation of extraterrestrial origin $(\lambda<8 \mathrm{~mm})$ is strongly absorbed by the Earth's atmosphere. In this regard, organisms could not have the natural mechanisms of adaptation to a significant intensity fluctuations due to external causes. However, they can adapt to their own similar fluctuations. In other words, the high sensitivity of living organisms to EMR of millimetric wavelength range is only the characteristic of endogenous origin.

This idea stimulated numerous studies to establish the regularities of interaction of low intensity EMR with organisms and also gave some impetus to the development of physiotherapeutic devices of new generation. But it should be noted that this idea only partially reflects the diversity of interaction of EMR with living organisms. It is not possible:

- to prove the evolutionary nature of the operating role of millimetric range of wavelengths, the most efficient time-frequency signal structure for medical purposes;

- to establish the role of other wavelength ranges, and their interrelation for the solution of problems of correction of homeostasis violations in organisms;

- to find out the relationship of low intensity EMR of natural and anthropogenic origin, etc.

The theoretical aspect of the research is based mainly on the totality of the proposed hypotheses following the results of the made experiments. Researchers adhering to the idea of resonant interaction of organisms with EMR continue to search for the "optimum" carriers in the millimeter wavelength range, and the most appropriate for their modulations. Despite the fact that in recent years, the representatives of the scientific school of Acad. N.D. Devyatkov received a large amount of experimental data on these problems, any progress in understanding the mechanisms which are its cornerstone doesn't exist. Moreover,

\footnotetext{
${ }^{1}$ Microwave radiation is the electromagnetic radiation including the decimeter, centimetric and millimetric range of radiowaves (wavelength from $1 \mathrm{~m}$ - the frequency of $30 \mathrm{MHz}$ to $1 \mathrm{~mm}-300 \mathrm{GHz}$ ) radiations of microwave range.
} 
a certain tendency can be seen that the accumulation of information on organism interaction with physical environmental factors doesn't clarity the question. The reason is one: the information capacity of the biota is many orders of magnitude higher than that predicted by researchers even half a century ago [7].

The above is the main result of researches conducted over the past decade within the ideas formulated by Acad. N.D. Devyatkov.

The further development of the idea of resonant interaction of biological objects is associated with electromagnetic radiation in the terahertz range ${ }^{2}$.

Studies of the last decade indicate that the electromagnetic radiation at the absorption and emission frequencies of the molecules - metabolites ( $\mathrm{NO}, \mathrm{CO}, \mathrm{CO}_{2}, \mathrm{O}_{2}, \mathrm{OH}$, etc.) can have a powerful effect on many regulatory processes in an organism [8]. Implementation under the influence of the biological effects of terahertz electromagnetic radiation is carried out at the molecular, subcellular, cellular, tissue, organ, system, and organism levels. One of the most important molecular mechanisms of terahertz waves is a change in the activity of enzymes and enzyme systems in cells.

At the same time, the lack of evolutionary conditionality of high sensitivity to electromagnetic radiation in the terahertz range ${ }^{3}$ limits the versatility of the radiation applied to the individual characteristics of the organism under certain diseases.

This feature of the EMR in the terahertz range, which is typical for EMR millimeter-wave $(\lambda<8 \mathrm{~mm})$, in conjunction with the existing problems of application of radiation for medical purposes, determined the emergence of yet another promising research area for the study of the actual problems of the organism interaction with electromagnetic radiation in the microwave range . This direction is connected with the scientific school of prof. S.N. Darovskikh and prof. E.P. Popechiteleva [9].

The conceptual basis is the statement about the operating role in wildlife of an electromagnetic factor of exogenous origin.

Thus the main and unconditional source of information of exogenous origin for organisms is the cosmic microwave background. It includes not only the microwave radiation of the Sun and our Galaxy, but also the relic radiation of the center of the Universe found in 1965 by the American scientists A. Penzias and R. Wilson [10]. The operating role of the specified electromagnetic radiations reaching Earth surface through the so-called, "radio window" on wavelengths from $8 \mathrm{~mm}$ to $15 \mathrm{~m} \mathrm{[11]} \mathrm{is} \mathrm{caused}$ by their impact on objects of wildlife at all stages of their evolution. At the same time as experimental studies demonstrated [12], the biologically active portion of the spectrum of this radiation is the centimeter wavelength range.

Currently the natural electromagnetic background caused by cosmic factors will be subjected substantially to distortion due to exposure of electromagnetic radiation (EMR) of an anthropogenous origin. These radiations define for organisms new negative properties of the environment of their dwelling in the long term.

For restoration in organisms of the operating role of a natural electromagnetic factor in the conditions of electromagnetic pollution, the implementation of the requirement according to which the excess of intensity of an anthropogenous microwave background over a natural background has to be minimum is essentially important. In most cases this requirement is impracticable. Therefore a compulsory measure is the procedure of artificial strengthening of natural electromagnetic radiation or its simulated ana$\log$ to the level comparable with an anthropogenous background (Fig. 1). The last circumstance reveals the essence of the hypothesis of a necessary condition of restoration in organisms of the operating role of a natural electromagnetic factor.

The implementation of this hypothesis is focused on "inclusion"by means of hardware of the evolutionary formed mechanisms to control organism homeostasis. The new conceptual framework allows to take into account the modern realities of electromagnetic pollution and to determine the directions for the development of the time-frequency structure of the EMR for medical purposes, and new hardware (hardware and software) means for their realization.

\footnotetext{
${ }^{2}$ Electromagnetic waves which frequency is in interval between $100 \mathrm{GHz}\left(1 \mathrm{GHz}=10^{9} \mathrm{~Hz}\right)$ and 30 terahertz $\left(1 \mathrm{THz}=10^{12} \mathrm{~Hz}\right)$ are called terahertz radiation. Wavelength of such radiation is in the range $(0,001-0,3) \mathrm{cm}$, i.e. between distant infrared and submillimetric $(<1 \mathrm{~mm})$ radiation.

${ }^{3}$ The organisms evolution in the foreseeable past isn't connected with electromagnetic radiations in the terahertz range. These radiations which main source is the Sun, are completely absorbed by the atmosphere of Earth.
} 


\section{Инфокоммуникационные технологии и системы}

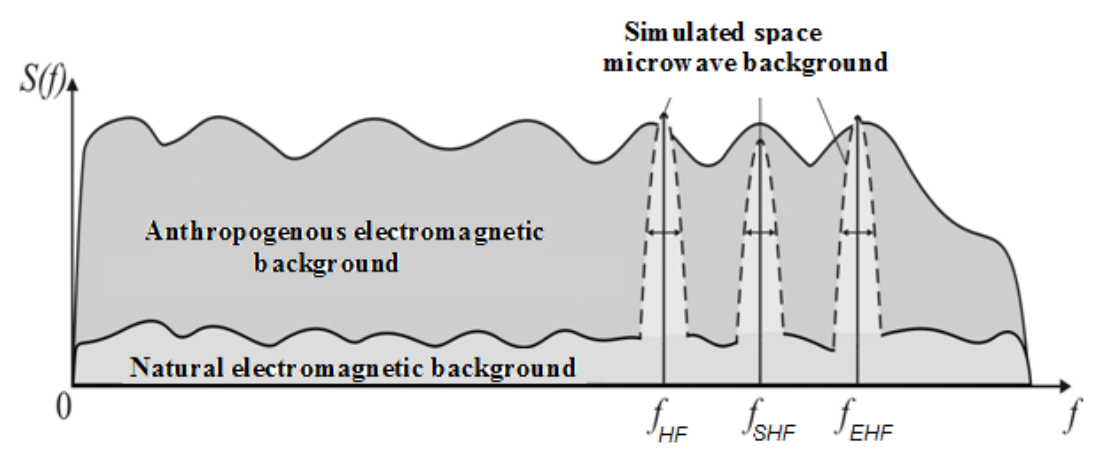

Fig. 1.The explanation of the hypothesis of the recovery of the operating role in Nature of a natural electromagnetic background

Based on the above, we formulated the following basic principles of creation of devices for recovery of the disturbed homeostasis [12]:

- the use of single-channel or multi-channel wideband generators in the range of microwave radiation of near and far space natural sources, reaching the Earth surface, which can provide the emission of electromagnetic energy with different types of polarization and flux densities comparable with the intensity of an electromagnetic background of anthropogenic origin;

- the use of actual parameters of low-frequency fluctuations of the cosmic microwave background or their analogs, which are formed by hardware or software for frequency and amplitude modulation of high-frequency radiations

Currently several versions of hardware and software for implementing the above-mentioned principles of their construction are developed [13].

The most perspective of them at practical use in National Health Service and in everyday life are autonomous (Fig. 2) and IBM compatible (Fig. 3) hardware and software for recovery of disturbed organism homeostasis by means of electromagnetic radiations of microwave range (range of frequencies $(4,0-4,3 \mathrm{GHz})$.

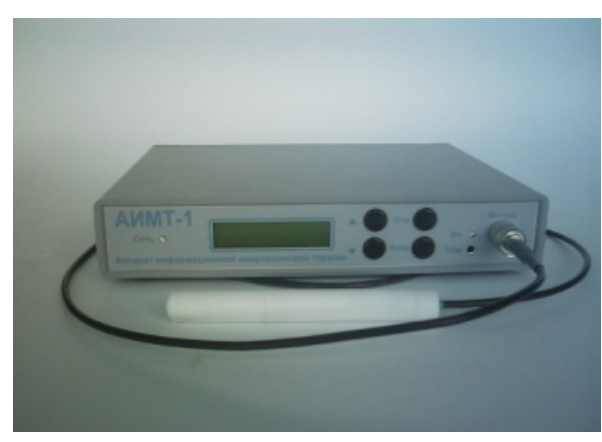

Fig. 2.The device of information microwave therapy

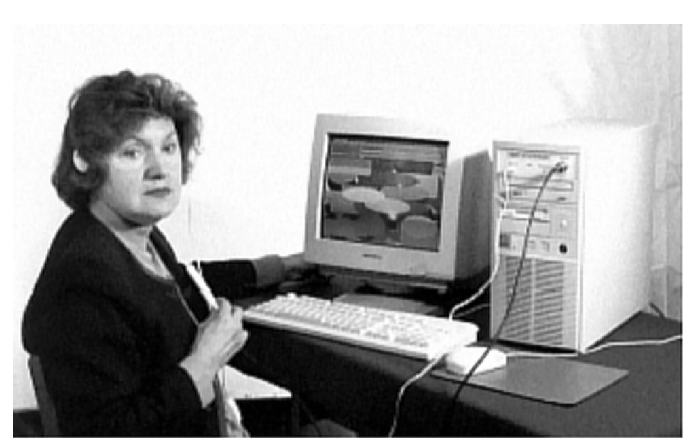

Fig. 3. The system equipment used during the medical procedure

For adequate simulation of high-frequency structure of the cosmic microwave background the hypothesis of the defining role in formation of amplitude-frequency structure of microwave radiation of the low-frequency fluctuations of a natural origin caused by processes of explosive character [12] was made.

In a series of experimental studies on various biological models by means of specially designed devices of the generation the following possible parameters of low-frequency fluctuations were grounded the following options for the low-frequency fluctuations of the cosmic microwave background [12]:

- the duration of the pulsations: $\tau=(0,01-1)$;

- the frequency range: $f=(20-20000) \mathrm{Hz}$;

- the change in each discrete frequency (pulse):either increases, or falls, or takes place both at a speed in the range $d f / d t= \pm(5-200) \cdot 10^{3} \mathrm{~Hz} \cdot \mathrm{s}^{-1}$;

- the period of the amplitude modulation: $T=(20-100)$ with its depth - to $50 \%$.

The above parameters have the uniform distribution law. 
Medicobiological researches of the developed hardware and software of restoration of the disturbed organism homeostasis by means of electromagnetic radiations of microwave range (range of frequencies $(4,0-4,3 \mathrm{GHz})$ showed high efficiency at autonomous and complex (together with medicines) treatment of a wide range of children and adult diseases [12]. The results of these studies demonstrate the scientific validity of the hypothesis of the operating role in wildlife of the microwave radiations of near and far space reaching Earth surface, and the basic principles of creation of hardware and software of their simulation for restoration of the disturbed organism homeostasis in the conditions of electromagnetic environmental pollution.

Noting the high efficiency of the developed hardware and software for microwave therapy in the treatment of a wide range of human diseases, it is necessary to pay attention to the fact that at the basis of the assessment of their effectiveness there is no information on the impact of their use in the electromagnetic radiation on microorganisms causing certain diseases.

The analysis of scientific publications in the field of microbiology on the problems of interaction of different types of microorganisms with EMR indicates the absence of the results of system studies taking into account the diversity of electromagnetic radiation (by origin, time-and-frequency structure, intensity etc.) and various species of microorganisms. It decreases the value of previous results of efficiency of the physiotherapy devices stated above.

Told above predetermined relevance of a series of experimental studies on the comparative assessment of the modifying action of low-intensity EMR of natural and anthropogenic origin to opportunistic microorganisms.

The main results of the conducted experimental studies on the example of fungi Candida and Staphylococcus aureus are $[14,15]$ :

- microwave radiation of an anthropogenous origin in the centimeter range is a factor of the accelerated growth of microorganisms and strengthening of their antibiotic-resistant properties. This allows to see the direct dependence of electromagnetic environmental pollution and the emergence of antibioticresistant strains of microorganisms;

- microwave simulated solar radiation reaching the Earth surface do not have a modifying effect on the microorganisms aimed at strengthening their resistant properties. Moreover their impact on microorganisms counters biofilm formation process. The basis of this phenomenon is "radio vibration" effect [16] at which there is a transformation of the absorbed electromagnetic energy to mechanical energy. This energy is the source of excitation in the biological structures of low-frequency elastic vibrations. Discovered during the research saccharolytic function activation of Staphylococcus aureus has an important modifying effect on him EMR of natural origin. It pulls together it on biochemical properties with saccharolytic bacteria, useful to an organism (bifido- and lactobacilli, enterokokk).

All this testifies to the prospects of using the EMR with the natural time-frequency structure to attenuate the pathogenic properties of a wide class of strains of microorganisms.

\section{Conclusion}

The analysis of the main directions, results and problems of scientific schools researches to assess EMR modifying action of various origin on the objects of wildlife, leads to the following conclusions:

1. Electromagnetic environmental pollution is a potentially dangerous factor of the environment of organisms dwelling. It can be the cornerstone of strengthening of resistant and as a result of pathogenic properties of different types of microorganisms.

2. The complex of unsolved problems associated with the use of the concept of resonant organism interaction with EMR of millimeter and submillimeter wavelengths limits the prospect of its use for medical purposes. The main reason for this conclusion is the absence of the account of evolutionarily significant role for organisms of microwave radiation from the Sun reaching the Earth surface.

3. For restoration of informative operating role of a natural electromagnetic factor in wildlife the use of hardware and software of simulation of microwave radiation of the Sun in the centimetric wavelength range is the most expedient.

4. Many general regularities of the activity of the studied microorganisms with other cellular structures of the human body, the "radio vibration" effect of their interaction with electromagnetic radiations of a natural origin opened by the authors give the grounds to make a positive outlook on the very important, but not yet investigated application of the exogenous approach to the restoration of disturbed ho- 


\section{Инфокоммуникационные технологии и системы}

meostasis. This application can be a "breakthrough" in the field of prevention of oncological diseases and treatment of their initial stages.

\section{References}

1. Chizhevskiy A.L. Zemnoe ekho solnechnykh bur' [Earth Echo of Solar Storms]. Moscow, Mysl' Publ., 1973. 347 p.

2. Gumilyov L.N. Etnogenez i biosfera Zemli [Ethnogenesis and Biosphere of the Earth]. St. Petersburg, Publishing House "Crystal", 2002. 639 p.

3. Presman A.S. Electromagnitnaya signalizatsiya $v$ zhivoy prirode. Fakty, gipotezy, puti issledovaniya [Electromagnetic Alarm in Nature. Facts, Hypotheses, Ways of Study]. Moscow, Sov. Radio Publ., 1974. $64 \mathrm{p}$.

4. Vernadskiy V.I. Zhivoe veshchestvo i biosfera [The Living Matter and the Biosphere]. Moscow, Nauka, 1994. 672 p.

5. Grigor'ev Y.G. [A Man in the Electromagnetic Field (the Current Situation, the Expected Biological Effects and Risk Assessment)]. Radiation Biology. Radioecology, 1997, vol. 37, no. 4, pp. 690-702. (in Russ.)

6. Devyatkov N.D., Golant M.B., Betsky O.V. Millimetrovye volny i ikh rol'v protsessakh zhiznedeyatel'nosti [Millimeter Waves and their Role in Life Processes]. Moscow, Radio and Communications Publ., 1991. 186 p.

7. Danilov-Danil'yan V.I. etc. Ekologicheskie problem:chto proiskhodit, kto vinovat i chto delat'? [Environmental Problems: What Happens, Who is to Blame and What to Do?]. Moscow, MNEPU Publ., 1997. $330 \mathrm{p}$.

8. Petrosyan V.I., Sinitsin N.I., Elkin V.A. [Fluorescent Interpretation of "SPE-effect"]. Biomedical Technology and Electronics, 2002, no. 1, pp. 28-38. (in Russ.)

9. Darovskikh S.N., Popechitelev H.E. Sovremennye aspekty postroeniya ustroystv informatsionnoy electromagnitnoy terapii [The Modern Aspects of Constracting of the Electromagnetic Therapy Devices]. Saarbruecken, Publishing House Laplambert, 2012. 241 p.

10. Zeldovich Ya.B., Novikov I.D. Stroenie i evolyutsiay Vselennoy [The Structure and Evolution of the Universe]. Moscow, Nauka Publ., 1975. 371 p.

11. Zheleznyakov V.V. Radioizluchenie Solntsa i planet [The Radioemission from the Sun and Planets]. Moscow, Nauka Publ., 1964, 560p.

12. Darovskikh S.N. Osnovy postroeniya ustroystv informatsionnoy electromagnitnoy terapii [Fundamentals of Electromagnetic Therapy Devices Construction]. Chelyabinsk: South Ural St. Univ. Publ., 2011. $138 \mathrm{p}$.

13. Darovskih S., Popechitelev E., Vdovina N., Novikov I. Modern Aspects of Construction of Information Microwave Therapy Devices. Natural Science, 2013, no. 5, pp. 1230-1237. Available at: http://dx.doi.org/10.4236/ns.2013.512150. DOI: 10.4236/ns.2013.512150.

14. Shishkova Yu.S., Darovskih S.N., Vdovina N.V. [Application of Simulated Low-level Microwave Radiation from the Sun to Reduce the Microwave Persistent Potential of Microorganisms and Increase of their Sensitivity to Antimicrobial Agents]. Materialy $V$ mezhdunarodnoy nauchnoprakticheskoy konferentsii "Fundamental'naya nauka i tekhnologii - perspektivnye razrabotki" [Materials of the V International Scientific and Practical Conference "Fundamental Science and Technologydevelopment Perspective", February 24-25, 2015]. North Charleston, USA, 2015, vol. 1, pp. 9-11. (in Russ.)

15. Darovskikh S.N., Shishkova Yu.S., Vdovina N.V., Shishkova E.V. [Comparative Assessment of Modifying Action of Microwave Radiation of Natural and Anthropogenic Origin on Staphylococcus Aureus]. Biomedical electronics, 2015, no. 3. pp. 50-55. (in Russ.)

16. Darovskikh S.N. Shishkova Yu.S., Vdovina N.V. [Radiophysical Technology to Increase the Sensitivity of Microorganisms to Antibiotics]. Materily mezhdunarodnoy nauchno-prakticheskoy konferentsii "Fundamental'nye i prikladnye nauki segognya [Materials of VI International Scientificpractical Conference "Fundamental and Applied Science Today", August 24-25, 2015]. North Charleston, USA, 2015, pp. 6-9. (in Russ.)

Received 29 December 2015 


\title{
О ПРОБЛЕМАХ ИССЛЕДОВАНИЯ ВЗАИМОДЕЙСТВИЯ ОРГАНИЗМОВ С МИКРОВОЛНОВЫМИ ИЗЛУЧЕНИЯМИ
}

\author{
С.Н. Даровских ${ }^{1}$, Ю. С. Шишкова ${ }^{2}$, Н.В. Вдовина ${ }^{1}$, Е.В. Водяницкий ${ }^{1}$ \\ ${ }^{1}$ Южно-Уральский государственный университет, г. Челябинск, \\ ${ }^{2}$ Южно-Уральский медицинский университет, г. Челябинск
}

\begin{abstract}
Представлен анализ основных проблем исследований взаимодействия организмов с электромагнитными излучениями микроволнового диапазона. Отмечен противоречивый подход в оценке роли микроволновых излучений искусственного происхождения для организмов: одни и те же излучения одна группа ученых рассматривает как потенциально опасные для организма, а другая утверждает, что при определенных условиях их можно использовать в лечебных целях. Указанное противоречие устраняется при использовании экзогенного подхода к оценке роли электромагнитных излучений в живой природе. В этой связи в статье обоснована управляющая роль в природе микроволнового излучения Солнца, достигающего поверхности Земли и необходимость использования устройств его моделирования для ослабления негативного влияния на организмы электромагнитного загрязнения окружающей среды. Приведены основные итоги микробиологических исследований с использованием разработанных аппаратно-программных средств моделирования микроволнового излучения Солнца в сверхвысокочастотном диапазоне длин волн.
\end{abstract}

Ключевые слова: гелиобиология, гомеостаз, микроволновые излучения, микроорганизмы.

\section{Лumepamypa}

1. Чижевский, А.Л. Земное эхо солнечных бурь / А.Л. Чижевский. - М.: Мысль, 1973. - 347 с.

2. Гумилев, Л.Н. Этногенез и биосфера Земли / Л.Н. Гумилев. - СПб.: СЗКЭО, ООО Издат. дом «Кристалл», 2002. -639 с.

3. Пресман, А.С. Электромагнитная сигнализация в живой природе. Факты, гипотезы, пути исследования / А.С. Пресман. - М.: Сов. радио, 1974. - 64 с.

4. Вернадский, В.И. Живое вещество и биосфера / В.И. Вернадский. - М.: Наука, 1994. - 672 c.

5. Григорьев, Ю.Г. Человек в электромагнитном поле (существующая ситуация, ожидаемые биоэффекты и оценка опасности) / Ю.Г. Григорьев // Радиаџионная биология. Радиоэкология. 1997. - T. 37, вып. 4. - C. 690-702.

6. Девятков, Н.Д. Миллиметровые волны и их роль в процессах жизнедеятельности / Н.Д. Девятков, М.Б. Голант, О.В. Беикий. - М.: Радио и связь, 1991. - 186 с.

7. Экологические проблемы: что происходит, кто виноват и что делать? / В.И. ДаниловДанильян и др. - М.: Изд-во МНЭПУ, 1997. - 330 с.

8. Петросян, В.И. Люминесиентная трактовка «СПЕ-эффекта» / В.И. Петросян, Н.И. Синицьин, В.А. Ёлкин // Биомедицинские технологии и радиоэлектроника. - 2002. - № 1. - С. 28-38.

9. Даровских, С.Н. Современные аспекты построения устройств информаиионной электромагнитной терапии / С.Н. Даровских, Е.П. Попечителев. - Саарбрюккен: Издат. Дом LAP Lambert, 2012. $-241 \mathrm{c}$.

10. Зельдович, Я.Б. Строение и эволюиия Вселенной / Я.Б. Зельдович, И.Д. Новиков - М.: Наука, 1975. $-371 \mathrm{c}$.

11. Железняков, В.В. Радиоизлучение Солниа и планет / В.В. Железняков. - М.: Наука, 1964. $560 \mathrm{c.}$

12. Даровских, С.Н. Основы построения устройств информационной электромагнитной терапии / С.Н. Даровских. - Челябинск: Издат. иентр ЮУрГУ, 2011. - 138 с.

13. Modern aspects of construction of information microwave therapy devices / S. Darovskih, E. Popechitelev, N. Vdovina, I. Novikov // Natural Science. - 2013. - no. 5. - P. 1230-1237. http://dx.doi.org/10.4236/ns.2013.512150. 


\section{Инфокоммуникационные технологии и системы}

14. Шишкова, Ю.С. Применение моделированного низкоинтенсивного микроволнового излучения Солниа СВЧ диапазона для снижения персистентного потенииала микроорганизмов и повышения их чувствительности к антимикробным препаратам / Ю.С. Шишкова, С.Н. Даровских, Н.В. Вдовина // Материаль V международной научно-практической конференции "Фундаментальная наука и технологии - перспективные разработки», 24-25 февраля 2015. - НортЧарлстон, США, 2015. - T. 1. - С. 9-11.

15. Сравнительная оценка модифищирующего действия микроволновых излучений природного и антропогенного происхождения на золотистый стафилококк / С.Н. Даровских, Ю.С. Шишкова, Н.В. Вдовина, Е.В. Шишкова // Биомедииинская радиоэлектроника. - 2015. - № 3. - С. 50-55.

16. Даровских, С.Н. Радиофизическая технология повышения чувствительности микроорганизмов к антибиотикам / С.Н. Даровских, Ю.С. Шишкова, Н.В. Вдовина // Материалы VI международной научно-практической конференции «Фундаментальные и прикладные науки сегодня», 24-25 августа 2015. - Норт-Чарлстон, США, 2015. - С. 6-9.

Даровских Станислав Никифорович, д-р техн. наук, профессор кафедры инфокоммуникационных технологий, Южно-Уральский государственный университет, г. Челябинск; darovskih.s@ mail.ru.

Шишкова Юлия Сергеевна, д-р мед. наук, профессор кафедры микробиологии, вирусологии, иммунологии и клинической лабораторной диагностики, Южно-Уральский медицинский университет; shishkova_yulia@mail.ru.

Вдовина Надежда Владимировна, старший преподаватель кафедры инфокоммуникационных технологий, Южно-Уральский государственный университет, г. Челябинск; nadzh@yandex.ru.

Водяницкий Евгений Викторович, аспирант кафедры инфокоммуникационных технологий, Южно-Уральский государственный университет, г. Челябинск; prorock_92@mail.ru.

Поступила в редакцию 29 декабря 20152.

\section{ОБРАЗЕЦ ЦИТИРОВАНИЯ}

About the Problems of the Research of Organisms Interaction with the Microwave Radiation / S.N. Darovskikh, Yu.S. Shishkova, N.V. Vdovina, E.V. Vodyanitskiy // Вестник ЮУрГУ. Серия «Компьютерные технологии, управление, радиоэлектроника». - 2016. - Т. 16, № 1. C. $43-50$. DOI: $10.14529 /$ ctcr160104

\section{FOR CITATION}

Darovskikh S.N., Shishkova Yu.S., Vdovina N.V., Vodyanitskiy E.V. About the Problems of the Research of Organisms Interaction with the Microwave Radiation. Bulletin of the South Ural State University. Ser. Computer Technologies, Automatic Control, Radio Electronics, 2015, vol. 16, no. 1, pp. 43-50. DOI: 10.14529/ctcr160104 